\title{
The Application of a Combined Delphi-AHP Method in Maritime Transport Research-A Review
}

\author{
Aminuddin Md Arof ${ }^{1,2}$ \\ ${ }^{1}$ Universiti Kuala Lumpur, Malaysian Institute of Marine Engineering Technology, Lumut, Malaysia \\ ${ }^{2}$ Malaysian Institute of Transport, Universiti Teknologi Mara, Shah Alam, Malaysia \\ Correspondence: Aminuddin Md Arof, Universiti Kuala Lumpur, Malaysian Institute of Marine Engineering \\ Technology, Pantai Remis Road, Lumut, Malaysia. Tel: 60-13-672-1480.E-mail: aminuddin@unikl.edu.my
}

\author{
Received: June 20, 2015 Accepted: September 14, 2015 Online Published: September 17, 2015 \\ doi:10.5539/ass.v11n23p73 \\ URL: http://dx.doi.org/10.5539/ass.v11n23p73
}

\begin{abstract}
Although the Delphi and AHP techniques have been extensively utilised in maritime transport research, the application of a combination of both techniques together in this sector is still limited. Hence, this paper aims to review the application of a combined Delphi and AHP method in maritime transport research through a literature review process. Among others, this study looks into the area of research, the number of expert respondents employed, the minimum prerequisite set for the selection of respondents and whether there is a similarity of respondents in both the Delphi and AHP techniques. In a period that spans around 11 years between 2004 and 2014, it has been discovered that only a total of 8 studies involving the shipping and port sub-sectors have applied the combined method. It is hoped that this review could provide some guidance to researchers in the maritime transport or other relevant areas on how the combined technique could be implemented in future research.
\end{abstract}

Keywords: maritime transport, Delphi, analytic hierarchy process (AHP)

\section{Introduction}

Over the years, maritime transport has grown into a specialised field of research. This is evidenced from the increasing number of journals and conferences dedicated to maritime transport. This is not surprising because of the prominent role played by maritime transport in facilitating global trade. The recent report published by the United Nations Conference on Trade and Development (UNCTAD) indicated that about 80 percent of global merchandise trade by volume and 70 percent of the trade by value are transported by ships and handled by ports worldwide in 2013 (UNCTAD, 2014). Due to its increasing role as a global trade facilitator, maritime transport has to endure various types of challenges that have become increasingly complex. Owing to the complexity of the problems, different aspects of the unit of analysis have to be taken into account as the consequences of the problems are normally far reaching. In addressing this difficulty, complex decision making processes have been undertaken to enable the achievement of a desirable outcome. Among the main issues currently being analysed in maritime transport are low freight rate, soaring bunkering prices, environment sustainability, port efficiency, investment in bigger vessels and short sea shipping as an alternative to road transportation. Among the common methods used to analyse problems in the maritime transport sector are the Delphi technique and the Analytic Hierarchy Process (AHP). Ever since they were introduced in 1963 and 1980 respectively, both methods have been extensively used either individually or in combination with other methods in the research process.

\section{Aim}

This paper aims to review the application of a combined Delphi and AHP technique in maritime transport research through a literature review process from accessible literature until early 2015 that could be traced through the Google Scholar as well as through the Mara University of Technology E-journal integrated search engine. It is hoped that this review could provide guidance to researchers in the maritime transport or other relevant areas on how the combined technique could be implemented in future research.

\section{The AHP}

The AHP is a type of Multi-Criteria Analysis, which has been extensively applied in research due to its suitability to address complicated and unstructured problems. The instrument that was developed by Saaty in 
1980 is a method that uses hierarchical model comprising levels of goal, criteria, sub-criteria and alternatives (Saaty, 2008). Among the important strengths of the AHP method is its ability to integrate either subjective and objective perceptions, or tangible and intangible assessments based on simple pair-wise comparison matrices (Saaty, 1986) (Da Cruz, Ferreira, \& Azevedo, 2013). It has been described as an easy and useful methodology to enable a pair-wise comparison within the analyst area of expertise to be carried out (Oguztimur, 2011). AHP uses the concept of paired comparison and hierarchical structure or network analysis for the selection of the most suitable alternative among a set of feasible choices (Saaty, 1997). The primary goal of an AHP is to select an alternative that best satisfies a given set of criteria out of a set of choices or to determine the weight of the criteria in any application using the decision maker's or expert's experience or knowledge in a matrix of a pair-wise comparison of attributes (Saaty, 2008). In decision making, AHP emphasises on the requirements to (1) identify the problem to be addressed; (2) the purpose or objective of the decision; (3) the criteria and sub-criteria to be analysed; (4) the stakeholders and groups that will be affected by the decision making; and (5) the alternative actions available (Saaty, 2008). The decision making steps using an AHP method is tabulated as Table 1 below.

Table 1. The analytic hierarchy process (Source: Saaty, 2008)

\begin{tabular}{ll}
\hline STEP & ACTIVITIES \\
\hline First & $\begin{array}{l}\text { Determine the problem and the kind of knowledge required to address the problem } \\
\text { Development of a Decision Hierarchy as follows: } \\
\text { Top: Goal of Decision }\end{array}$ \\
Second & $\begin{array}{l}2^{\text {nd }}: \text { Identify the objectives from a broad perspective } \\
3^{\text {rd }}: \text { Identification of criteria involved }\end{array}$ \\
Bottom: Determine a set of alternatives \\
Third & $\begin{array}{l}\text { Construct a set of pair-wise comparison matrices } \\
\text { Fourth }\end{array}$ \\
& $\begin{array}{l}\text { Implement the priorities acquired from the pair-wise comparisons to weigh the overall value of the } \\
\text { alternatives }\end{array}$
\end{tabular}

In problem solving, there are three basic principles that one can identify i.e. the principles of decomposition, comparative judgments as well as synthesis of priorities (Saaty, 1986). In the AHP, the decomposition principle calls for constructing the hierarchy to identify the basic components of the problem to be addressed, whilst the principle of comparative judgment involves the pair-wise or paired comparisons (Saaty, 1986). According to Saaty, paired comparisons are the intermediate fine-structured process where the expert uses his or her best knowledge and understanding to decide the number of times the dominant of two factors, elements or alternatives, is a multiple of the less dominant one taken as the unit of measurement (Saaty, 1997). Finally, the synthesis of priorities principle is applied from the second level of the AHP model downward by multiplying the local priorities by the priority of their corresponding criterion in the higher level, including adding them for each element in a level in accordance to the criteria it affects (Saaty, 1986). Saaty espouses the use of a fundamental scale of absolute numbers between 1-9 that have been proven in many experiments to have produced excellent results as compared to other scales such as 1-3 or 1-5 that have not delivered good results (Saaty, 1997) (Bodin \& Gass, 2003). As an extension of Saaty's priority theory, authors have further strengthened the 1-9 scale on absolute numbers to fuzzy numbers, which were argued as an alternative for decision makers to express their essentially fuzzy and uncertain perception or judgements in fuzzy numbers to enable for more realistic results as compared to using the absolute numbers (Van Laarhoven \& Pedrycz, 1983) (Kwiesielewicz, 1998) (Kwong \& Bai, 2002) (Kuo, Chi, \& Kao, 2002). However, the introduction of fuzzy numbers for the AHP is opposed by Saaty who argues that the judgments using the AHP scale is already fuzzy. As a result, making them fuzzier could only worsen the outcomes in some instances (Saaty \& Tran, 2007).

\section{Delphi Technique}

The Delphi technique was first developed by RAND Corporation in the United States in 1950s. However, it was only introduced by Dalkey and Helmer in 1963 in order to assess variables that are intangibles or covered in an uncertainty by extricating on the knowledge and experience of a diverse group of experts through a method of anonymous and iterative consultation (Dalkey \& Helmer, 1963) (Grisham, 2009). It is hereby useful in a situation whereby individual judgments must be tapped and brought together in order to address a lack of agreement or in a situation with an incomplete state of knowledge on the research area (Powell, 2003). Four key 
features that need to be adhered in the Delphi procedure are the anonymity of Delphi panels, iteration that allows panellists to refine their views, controlled feedback and statistical aggregation of group response that allows for quantitative analysis and interpretation of data (Rowe \& Wright, 1999). Nevertheless, the earlier Delphi literature only emphasises on the mandatory requirements of iteration and anonymity of Delphi panels (Dalkey \& Helmer, 1963). In fact, the identity of the expert respondents is commonly not revealed, even after the completion of the final report (Sekaran \& Bougie, 2010). The anonymity given would prevent some respondents from dominating others, allowing all expert respondents to unconditionally express their opinions and encourage them to admit any mistake made by reviewing their earlier judgments (Sekaran \& Bougie, 2010).

This technique has been described as a method well-suited for consensus-building through the use of a series of questionnaire delivered using multiple iteration process to collect data from a panel of selected experts (Hsu \& Sandford, 2007) (Grisham, 2009). It is considered as a qualitative, long-range forecasting technique by some (Gupta \& Clarke, 1996) or a mixture of both qualitative and quantitative techniques by some others (Steward, 2001). A review through the literature have seen authors dividing the Delphi technique into a Classical Delphi, which is based on its original form, a Decision Delphi as a forum for structuring decision and a Policy Delphi to generate opposing views on policy and potential resolutions (Hasson \& Keeney, 2011) (Steward, 2001). Other than the three common types of Delphi technique, others such as Modified, Real time, e-Delphi, Technological, Online, Argument and Dis-aggregative policy could also be traced (Hasson \& Keeney, 2011). Since it was first introduced, the Delphi has been successfully applied in various fields involving program planning, needs assessment, resource utilisation and policy determination (Hsu \& Sandford, 2007). It has been described "to have filled a deep need of academics and practitioners for structured ways of assessing and combining human judgments" (Rowe \& Wright, 2011). Rowe and Wright (2011) in their study on the past, present and future prospects of Delphi, discover that in numerous cases in seems to be a technique that allows researchers to ask and answer questions that they did not previously have the knowledge on how to address. The types of Delphi designs can be summarised as per Table 2 below.

Table 2. Types of delphi designs (Source: Hasson \& Keeney, 2011; Linstone \& Turoff, 2011)

\begin{tabular}{|c|c|c|c|c|c|}
\hline Design Type & Aim & Target panellists & Administration & $\begin{array}{l}\text { Numbers } \\
\text { of rounds }\end{array}$ & $\begin{array}{l}\text { Design of Round } \\
\text { One }\end{array}$ \\
\hline Classical & $\begin{array}{l}\text { Extract opinion and } \\
\text { gain consensus }\end{array}$ & $\begin{array}{l}\text { Experts designated } \\
\text { based on research } \\
\text { objective }\end{array}$ & Traditionally postal & $\begin{array}{l}3 \text { or more } \\
\text { rounds }\end{array}$ & $\begin{array}{l}\text { Open-ended } \\
\text { qualitative to allow } \\
\text { panellists to freely } \\
\text { provide responses }\end{array}$ \\
\hline Modified & $\begin{array}{l}\text { Varies according to } \\
\text { research design from } \\
\text { predicting future } \\
\text { events to achieving } \\
\text { consensus }\end{array}$ & $\begin{array}{l}\text { Experts designated } \\
\text { based on research } \\
\text { objective }\end{array}$ & $\begin{array}{l}\text { Varies, postal, } \\
\text { online, etc. }\end{array}$ & $\begin{array}{l}\text { May } \\
\text { employ } \\
\text { less than } 3 \\
\text { rounds }\end{array}$ & $\begin{array}{l}\text { Pre-selected items, } \\
\text { drawn from } \\
\text { various sources are } \\
\text { provided, within } \\
\text { which panellists } \\
\text { are asked to } \\
\text { consider their } \\
\text { responses }\end{array}$ \\
\hline Decision & $\begin{array}{l}\text { Structure } \\
\text { decision-making and } \\
\text { create the future in } \\
\text { reality instead of } \\
\text { predicting it }\end{array}$ & $\begin{array}{l}\text { Decision makers } \\
\text { based on } \\
\text { hierarchical } \\
\text { position and level } \\
\text { of expertise }\end{array}$ & Varies & Varies & $\begin{array}{l}\text { May use similar } \\
\text { process to classical } \\
\text { Delphi }\end{array}$ \\
\hline Policy & $\begin{array}{lr}\text { Generate } & \text { opposing } \\
\text { opinions on policy } \\
\text { and } & \text { general } \\
\text { resolutions } & \end{array}$ & $\begin{array}{lr}\text { Policy } & \text { makers } \\
\text { nominated } & \text { to } \\
\text { obtain differing } \\
\text { opinions } & \text { and } \\
\text { identify the most } \\
\text { important differing } \\
\text { evidence } \\
\text { arguments }\end{array}$ & $\begin{array}{l}\text { May adopt a number } \\
\text { of formats including } \\
\text { bringing participants } \\
\text { together in group } \\
\text { meeting }\end{array}$ & Varies & $\begin{array}{l}\text { May use similar } \\
\text { process to classical } \\
\text { Delphi }\end{array}$ \\
\hline $\begin{array}{l}\text { Real time/ } \\
\text { consensus } \\
\text { conference }\end{array}$ & $\begin{array}{l}\text { To elicit opinion and } \\
\text { gain consensus }\end{array}$ & $\begin{array}{l}\text { Experts selected } \\
\text { according to } \\
\text { research objective }\end{array}$ & $\begin{array}{l}\text { Panellists use } \\
\text { computer } \\
\text { technology in the } \\
\text { same venue with } \\
\text { anonymity to }\end{array}$ & Varies & $\begin{array}{l}\text { May adopt similar } \\
\text { process to classical } \\
\text { Delphi. May also } \\
\text { be a near-real time } \\
\text { "roundless" Delphi }\end{array}$ \\
\hline
\end{tabular}




\begin{tabular}{|c|c|c|c|c|c|}
\hline Design Type & Aim & Target panellists & Administration & $\begin{array}{l}\text { Numbers } \\
\text { of rounds }\end{array}$ & $\begin{array}{l}\text { Design of Round } \\
\text { One }\end{array}$ \\
\hline & & & $\begin{array}{l}\text { achieve consensus in } \\
\text { real time }\end{array}$ & & method \\
\hline e-Delphi & $\begin{array}{l}\text { Aim varies depending } \\
\text { on the nature of } \\
\text { research }\end{array}$ & $\begin{array}{l}\text { Experts selection } \\
\text { can vary } \\
\text { depending on the } \\
\text { research objective }\end{array}$ & $\begin{array}{l}\text { Administration via } \\
\text { email or online } \\
\text { survey }\end{array}$ & Varies & $\begin{array}{l}\text { May utilise similar } \\
\text { process to classical } \\
\text { Delphi }\end{array}$ \\
\hline Technological & $\begin{array}{l}\text { Aim varies according } \\
\text { to research design, } \\
\text { from predicting future } \\
\text { events to achieving } \\
\text { consensus }\end{array}$ & $\begin{array}{ll}\text { Experts selected } \\
\text { based on research } \\
\text { objective }\end{array}$ & $\begin{array}{l}\text { Use of hand-held } \\
\text { keypads allowing } \\
\text { responses to be } \\
\text { recorded and instant } \\
\text { feedback provided }\end{array}$ & Varies & $\begin{array}{l}\text { May utilise similar } \\
\text { process to classical } \\
\text { Delphi }\end{array}$ \\
\hline Online & $\begin{array}{l}\text { Aim varies according } \\
\text { to research design, } \\
\text { from predicting future } \\
\text { events to achieving } \\
\text { consensus }\end{array}$ & $\begin{array}{ll}\text { Experts } & \text { selected } \\
\text { based on research } \\
\text { objective }\end{array}$ & $\begin{array}{l}\text { Technique } \\
\text { implemented on any } \\
\text { online instrument } \\
\text { such as forum or a } \\
\text { chat room }\end{array}$ & Varies & $\begin{array}{l}\text { May use similar } \\
\text { process to classical } \\
\text { Delphi }\end{array}$ \\
\hline Argument & $\begin{array}{l}\text { Develop relevant } \\
\text { arguments and expose } \\
\text { underlying reasons for } \\
\text { different opinions on a } \\
\text { specific single issue }\end{array}$ & $\begin{array}{l}\text { Expert respondents } \\
\text { should represent } \\
\text { the research issue } \\
\text { from different } \\
\text { perspectives }\end{array}$ & Varies & Varies & $\begin{array}{l}\text { May utilise similar } \\
\text { process to } \\
\text { modified Delphi }\end{array}$ \\
\hline $\begin{array}{l}\text { Disaggregative } \\
\text { policy }\end{array}$ & $\begin{array}{l}\text { Constructs } \text { future } \\
\text { scenarios } \\
\text { panellists are asked } \\
\text { regarding } \\
\text { probable and the } \\
\text { preferable future }\end{array}$ & $\begin{array}{l}\text { Expert selection } \\
\text { varies depending } \\
\text { on the research } \\
\text { objective }\end{array}$ & Varies & Varies & $\begin{array}{lr}\text { Adoption } & \text { of } \\
\text { modified } & \text { format } \\
\text { using } & \text { cluster } \\
\text { analysis } & \end{array}$ \\
\hline
\end{tabular}

Unlike other data gathering techniques, Delphi employs a multiple iterations technique to develop a consensus of opinion regarding the research topic, thus it allows the respondents to re-assess their initial judgments or the information provided in the earlier iteration (Grisham, 2009) (Skulmoski et al., 2007). Hence, this method allows and encourages the expert respondents to re-assess their initial judgments that were provided during the earlier iteration. In fact, two main elements of Delphi have been emphasised by its earlier proponents are iteration and anonymity. Dalkey and Helmer in the earlier paragraphs of their introductory article on the Delphi technique emphasises that it "..involves the repeated individual questioning of the experts (by interview or questionnaire) and avoid direct confrontation of experts with each other" (Dalkey \& Helmer, 1963). Similarly, Linstone and Turoff, whose role in bringing notice of the Delphi to a wider audience through their book in 1975 re-emphasise in their recent article that the Delphi's key features are the "preservation of anonymity in the expert panel's responses and iteration of the questionnaires" (Linstone \& Turoff, 2011).

Anonymity has been emphasised over the literature as important to reduce the effects of dominant individuals, which is often a concern when using a group-based decision making technique and is considered important to avoid direct confrontation between the expert respondents (Dalkey \& Helmer, 1963) (Hsu \& Sandford, 2007). With the present technological innovation, the confidentiality of respondents can be further protected through the use of electronic communication such as email particularly among experts that are geographically dispersed. In fact, Linstone and Turoff describe the electronic age as providing better opportunities for Delphi technique, especially in the context of increasing citizen and stakeholder involvement (Linstone \& Turoff, 2011).

The controlled feedback process normally consists of a well-organised summary of the prior iteration deliberately disseminated to allow the respondents an opportunity to generate additional insights and thoroughly elucidate the information provided through the preceding iteration. Through this process, the respondents are expected to become more problem-solving oriented, to offer their opinion more insightfully and minimise the effects of noise i.e. data distortion that occurred due to individual or group interests (Hsu \& Sandford, 2007). It has the advantage over direct confrontation of experts that often induces a hastily formulation of preconceived ideas, an inclination to disregard novel idea, a tendency to defend an earlier judgment and a possibility to be swayed by persuasively stated views of others (Dalkey \& Helmer, 1963). On the other hand, the possibility to use a variety of statistical analysis techniques allows for an objective and impartial analysis and dissemination of 
the collected data (Hsu \& Sandford, 2007). Although the first round questionnaire could be unstructured to seek an open response that would require a qualitative analysis, the second and subsequent rounds are described as more specific, with the questionnaires seeking for the quantification of earlier findings through ranking or rating techniques (Powell, 2003) (Stewart, 2001).

\section{A Combined Delphi-AHP Technique}

It is not something new for researchers to combine the usage of the Delphi technique with the AHP technique in their research. Whilst the Delphi technique is used at the preliminary stage of their research in order to shortlist and identify the more prominent variables, the AHP has been used as the subsequent stage to determine the weightage of the selected variables and develop the decision making model required (Da Cruz et al., 2013; Chung \& Her, 2013; Lee, Wan, Shi, \& Li, 2014; Moradi, Etebarian, Shirvani, \& Soltani, 2014; Sayareh \& Alizmini, 2014). The combination of the two techniques could be traced in many research areas such as project management (Lee \& Kim, 2001; Vidal, Marle, \& Bocquet, 2011), logistics (Cheng, Chen, \& Chuang, 2008), supply chain management (Cheng \& Tang, 2009), strategic planning (Gerdsri \& Kocaoglu, 2007), forecasting (Mishra, Deshmukh, \& Vrat, 2002), product development (Yang, Liu, Kao, \& Wang, 2010; Cho \& Lee, 2013), supplier selection (Cheng, Lee, \& Tang, 2009; Liao, 2010), human resource management (Tavana, Kennedy, \& Joglekar, 1996), safety (Moradi et al., 2014; Chung \& Her, 2013) and transportation (Lee et al., 2014).

In the maritime transport sector, Da Cruz et al. (2013) in their study on seaport competitiveness utilised the Delphi technique to determine the more important factors from the 12 factors identified through the literature review. As a result, only 5 determining factors were selected for the AHP pair-wise comparisons (Da Cruz et al., 2013). For the Delphi survey, 22 experts from the academicians and industry were used whilst a total of 24 liner shipping companies and 30 seaport service providers responded to the AHP questionnaire that was posted online (Da Cruz et al., 2013). Da Cruz (2013) defines experts as professionals with more than 5 years of experience in the shipping industry and academicians who have 10 or more international publications. In another study, Lee et al. (2014) use this combined technique in their examination of the competitiveness of the international shipping industry. They utilised the contribution of 7 experts to identify the main factors from the 31 factors obtained through literature review and expert interviews (Lee et al., 2014). As a result, 24 main factors were identified and the judgments of 36 expert respondents were utilised for the AHP techniques (Lee et al., 2014). The experts in this study are those from the shipping industry, government and academicians with more than 5 years related experience (Lee et al., 2014).

In developing a model for Iran marine casualties management using a combination of Delphi and AHP techniques, Moradi et al. (2014) performed interviews with 20 experts from the shipping industry, academic community and government authorities to identify the prominent factors from the 43 items identified through the literature review process. Subsequently, AHP evaluation was done by 20 experts from shipping, government agencies and various related sectors on 31 factors that were shortlisted using the Delphi technique (Moradi et al., 2014). For their study in Iran, Moradi et al. (2014) define experts as those having at least 20 years of experience in the related field. In another study in the Persian Gulf area, Sayareh \& Alizmini (2014) utilised the judgments of 25 experts from the academia, shipping companies and ports to shortlist 61 factors identified through a literature review process that are considered important in selecting the most suitable container port in the Persian Gulf. The two-round Delphi technique has shortlisted only 16 very important and decisive factors in port selection. However, the number of expert respondents involved in the AHP evaluation was not specified. In this study, senior and middle managers in the shipping, port, shipping agents, regional forwarders and academicians are considered as experts for the Delphi process (Sayareh \& Alizmini, 2014). In developing the AHP model, the pair-wise comparisons were replaced by a Technique for Order Preference to Similarity by Ideal Solution on better known as TOPSIS. In their AHP evaluation, expert respondents were recruited from port operators, regional liner managers, shipping agent, regional forwarders and academicians (Moradi et al., 2014). However, the number of respondents for the AHP exercise was not given.

In an earlier study on a global perspective of transhipment port selection where a total of 47 service attributes were initially identified through a literature review process, a two-round Delphi survey technique utilised the judgments of 10 experts from the academia and the shipping industry in Taiwan. The conclusion of the Delphi survey was the identification of 4 main service attributes that could be further divided into 12 sub-criteria (Lirn et al., 2004). As for the AHP evaluation, the services of 30 expert respondents from the top 20 container shipping companies and top 20 container ports across the globe were utilised (Lirn et al., 2004). All expert respondents were involved in the AHP pair-wise comparisons between the different major criteria and sub-criteria, whilst the last part of the questionnaire for the purpose of evaluating the performance of the selected container ports was only sent to experts from the shipping companies (Lirn et al., 2004). In this study, when the answer in the AHP 
survey was found to be inconsistent, the researcher followed up the respondents, asking them to consider revising their responses as suggested by Forman and Selly (Forman \& Selly, 2001)(Lirn et al., 2004). However, the seniority level and experience of the expert respondents involved in this study were not highlighted by the authors other than the industries they represented (Lirn et al., 2004).

In another research involving a combination of Delphi and AHP techniques in the maritime transport sector, Gagatsi et al. (2014) utilised the judgements of 8 expert respondents from the academic and research communities in a two round-Delphi survey to facilitate for the development of an evaluation matrix. This matrix is part of their research requirement to achieve their aim of proposing an operational strategy to facilitate for a policy making in maritime transport sector (Gagatsi et al., 2014). Subsequently an AHP survey was conducted on 78 maritime transport companies involving shipping, ports, local representatives and their associations. In this exercise, the stakeholders were requested to conduct pair-wise comparisons on the four main criteria identified in the earlier Delphi survey (Gagatsi et al., 2014). In another study on the Port State Control (PSC) Perception of Safe Management of Bulk Carriers, a three round-modified Delphi technique was used using a questionnaire survey on experts in order to provide the probability of occurrence for the given defect or non-conformance onboard bulk carriers in a PSC inspection (Chung \& Her, 2013). Once the Benefits, Opportunities, Costs and Risks (BOCR) model was developed, the AHP technique was used to allow the experts to perform pair-wise comparisons among the 4 criteria and 16 deficiencies that formed the sub-criteria (Chung \& Her, 2013). Finally, a study by Jeong (2014) utilised the combined Delphi-AHP method in a study on the activation strategy for female maritime officers in the Republic of Korea. This study has the aim to develop suitable strategy for female maritime officers to consider in addressing the shortage of seafarers in the near future. A Delphi method was used to allow a panel of maritime experts to determine which of the ten external factors are the primary factors and the secondary factors. On the other hand, the AHP technique was used in a questionnaire survey on 130 female undergraduates from two maritime universities in Korea to perform pair-wise comparisons between three main clusters i.e. social climate, policy and working environment. The summary that can be drawn from the above studies involving a combination of the Delphi and AHP techniques is summarised in Table 3 as follows.

Table 3. Summary of Delphi-AHP studies

\begin{tabular}{|c|c|c|c|c|c|c|c|}
\hline No. & Author & $\begin{array}{l}\text { Research } \\
\text { Area }\end{array}$ & $\begin{array}{l}\text { No. of } \\
\text { Delphi } \\
\text { Experts }\end{array}$ & $\begin{array}{l}\text { No. of } \\
\text { AHP } \\
\text { Experts }\end{array}$ & \begin{tabular}{l}
\multicolumn{2}{l}{ Similarity } \\
between Delphi \\
$\& \quad$ AHP \\
respondents
\end{tabular} & $\begin{array}{l}\text { Selection of } \\
\text { alternatives }\end{array}$ & $\begin{array}{l}\text { Definition of Experts } \\
\text { (Minimum) }\end{array}$ \\
\hline 1. & $\begin{array}{l}\text { Lirn et al. } \\
(2004)\end{array}$ & Seaport & 10 & 30 & Not identified & $\begin{array}{l}18 \quad \text { AHP } \\
\text { respondents }\end{array}$ & $\begin{array}{l}\text { Suitable respondents from } \\
\text { shipping, ports \& } \\
\text { academia }\end{array}$ \\
\hline 2. & $\begin{array}{l}\text { Da Cruz et } \\
\text { al. (2013) }\end{array}$ & Seaport & 22 & 54 & Not identified & $\begin{array}{l}24 \quad \text { AHP } \\
\text { respondents }\end{array}$ & $\begin{array}{l}5 \text { years of experience in } \\
\text { maritime transport } \\
\text { industry \& } 10 \text { publications } \\
\text { for academics }\end{array}$ \\
\hline 3. & $\begin{array}{l}\text { Lee et al. } \\
(2014)\end{array}$ & Shipping & 7 & 36 & Not identified & $\begin{array}{l}36 \quad \text { AHP } \\
\text { respondents }\end{array}$ & $\begin{array}{l}5 \text { years of experience from } \\
\text { industry, government \& } \\
\text { academia }\end{array}$ \\
\hline 4. & $\begin{array}{l}\text { Moradi et } \\
\text { al. (2014) }\end{array}$ & Shipping & 20 & 20 & Not identified & - & 20 years of experience \\
\hline 5. & $\begin{array}{l}\text { Sayareh \& } \\
\text { Alizmini } \\
(2014)\end{array}$ & Seaport & 25 & $\begin{array}{l}\text { Not } \\
\text { stipulated }\end{array}$ & Not identified & - & $\begin{array}{l}\text { Middle level managers \& } \\
\text { academics }\end{array}$ \\
\hline 6. & $\begin{array}{l}\text { Gagatsi et } \\
\text { al. (2013) }\end{array}$ & Shipping & 8 & 78 & $\begin{array}{l}\text { Different } \\
\text { respondents }\end{array}$ & - & $\begin{array}{lr}\text { Academicians } & \& \\
\text { Researchers for Delphi. } \\
\text { Representatives from } \\
\text { companies } & \text { and } \\
\text { organisations for AHP }\end{array}$ \\
\hline 7. & $\begin{array}{l}\text { Chung \& } \\
\text { Her }(2013)\end{array}$ & Shipping & $\begin{array}{l}\text { Not } \\
\text { stipulated }\end{array}$ & $\begin{array}{l}\text { Not } \\
\text { stipulated }\end{array}$ & Not identified & - & $\begin{array}{l}\text { Experience } \\
\text { professionals }\end{array}$ \\
\hline 8. & $\begin{array}{l}\text { Jeong } \\
(2014)\end{array}$ & Shipping & $\begin{array}{l}\text { Not } \\
\text { stipulated }\end{array}$ & 130 & $\begin{array}{l}\text { Different } \\
\text { respondents }\end{array}$ & - & $\begin{array}{l}\text { Maritime experts for } \\
\text { Delphi \& female maritime } \\
\text { cadets for AHP }\end{array}$ \\
\hline
\end{tabular}




\section{Discussion}

Gleaning through the summary from Table 3, no consistent trend in the numbers and minimum qualification for expert selection could be traced from the literature review. There is a study that utilised similar number of expert respondents for both the Delphi and AHP surveys (Moradi et al., 2014). This trend could also be traced outside the maritime transport sector (Hsu \& Chen, 2007). However, more studies opted not to have similar number of respondents depending on the suitability of tasks. Some studies employed a bigger number of respondents for the AHP as compared to the initial stage of their studies involving the Delphi survey (Lirn et al., 2004; Da Cruz et al., 2013; Gagatsi et al., 2013; Lee et al., 2014). Nevertheless, other studies outside the maritime transport sector have also employed less number of AHP respondents as compared to the number used during the Delphi stage (Cheng \& Tang, 2009; Khademi \& Sheikholeslami, 2010; Vidal et al., 2011; Wu \& Fang, 2011). Through the literature examination, the variation in the number of participants generally depended on the level of expertise required, availability of experts and their willingness to participate in the study. The studies that employed more AHP respondents at Table 3 above mainly have the benefit of having the numbers of shipping and port operators with the required local knowledge to be engaged in the AHP analysis. Similarly, a study on university graduates allows for a high response rate because the respondents considered themselves as stakeholders that would benefit from the study (Jeong, 2014). On the contrary, studies that employed less AHP respondents compared to the other studies were mainly restricted by the availability of expertise particularly with the required knowledge on the area under examination (Lirn et al., 2014; Moradi et al., 2014).

As for the level of expertise required, some studies have emphasised on persons with long experience of 20 years or more to qualify as expert respondents (Moradi, 2014). Other studies have imposed the requirement of holding suitable management positions such as middle level management and above (Sayareh \& Alizmini, 2014). However, several studies indicate a minimum of five years of relevant experience (Da Cruz et al., 2013) (Lee et al., 2014), as well as suitable publications for academicians (Da Cruz et al., 2013). However, there are studies outside the maritime transport sector that require expert respondents from the academia to be at a minimum level of Professor or Assistant Professor (Cheng \& Tang, 2009; Khademi, 2010). Hence, it can be surmised that the minimum requirement of expertise to be imposed as a pre-condition to be selected as expert respondents generally depends on the complexity of the problem to be examined. Another important reason is the consideration on the availability of the experts if the pre-requisite is too high such as in the case of Hsu \& Chen (2007) in a study involving the supply chain industry that only requires people with suitable knowledge in the bicycle industry due to the limited number of experts available.

Since the Delphi technique involves consultation with a group of expert panel members, it is imperative for researchers to observe a procedure to obtain the most reliable consensus through a series of intensive questionnaires interspersed with a controlled opinion feedback (Gordon, 2009; Rowe \& Wright, 1999). Hence, the number of expert judgments to be utilised will generally depend on the topic, the geographical area and availability of suitable experts. Even when Delphi technique was first introduced by RAND corporation, the number of experts recruited for the study was only 7 (Dalkey \& Helmer, 1963). Subsequently, Delbecq et al. (1975) argue that 10 to 15 experts should be sufficient, whilst Ludwig (1997) argues that majority of the Delphi studies utilised around 15 to 20 respondents. In order to further determine the common number of experts utilised for Delphi technique, Rowe and Wright (1999) have search through 9 computer databases namely ABI Inform Global, ERIC, Applied Science and Technology Index, General Science Index, Transport< Econlit, INSPEC, Sociofile and Psychlit. It was discovered that the number of respondents ranges from just 3 to 98 experts, where 17 out of 27 studies traced utilised a purposive sampling size of less than 10 experts, while another 7 studies utilised between 10 to 20 expert respondents (Rowe \& Wright, 1999). Similarly, Skulmoski, and Hartman (2007) in their review of graduate research that have utilised the Delphi technique, listed the number of respondents of between 3 to 171, with 4 out of 16 utilising less than 10 expert judgments and 7 other studies utilised between 10 to 30 respondents. On the contrary, the AHP is meant to help an individual to organise his thinking in order to assist him in dealing with many decisions with a process that allows him to experiment with different criteria and different judgments (Saaty, 2002). However, due to its ability to combine tangible and intangible variables in addressing complex problems, AHP is also useful when many interests are involved and a number of people need to participate in the judgment process to represent their various interests (Saaty, 1986).

\section{Conclusion}

In retrospect, it has been observed that although the Delphi and AHP techniques have been extensively utilised in the maritime transport research, the utilisation of a combination of both techniques together in this sector is still limited. This is understandable because the Delphi technique can be considered as a more challenging technique 
as compared to some other techniques due to the requirements of iteration and controlled feedback. The two preceding imperatives entail the Delphi survey or interview to be administered on the same expert respondents in a minimum of two to three rounds until a consensus is achieved. Hence, in many research the Delphi technique has been traced to be utilised individually rather than in concert with other techniques. On the contrary, the AHP technique has been traced to be utilised more often with other methods particularly focus group discussion, brain storming and SWOT analysis. Although, it is a challenge to retain the interest of expert respondents in a research, one of the main advantages of the Delphi technique is that there is no requirement for a minimum number of respondents to participate in the research. However, at the end of the Delphi process, there need to be an adequate number of respondents for an acceptable conclusion to be drawn. Another main advantage is that it could be administered separately to experts that are geographically dispersed. Hence, the utilisation of a combined Delphi-AHP method is arguably suitable in maritime transport research particularly in study areas that do not have many experts that could participate. In addition, this combined method augurs well with maritime transport experts that are also geographically dispersed due to the globalised nature of maritime transport operations.

\section{Acknowledgements}

The author would like to extend his appreciation to Universiti Kuala Lumpur for the research grant provided under the Short Term Research Grant Scheme; the Malaysian Institute of Transport, Mara University of Technology for providing a conducive environment to conduct this research; and anonymous reviewers for their constructive comments on the earlier draft.

\section{References}

Bodin, L., \& Gass, S. I. (2003). On teaching the analytic hierarchy process. Computers and Operations, 30, 1487-1497. http://dx.doi.org/10.1016/S0305-0548(02)00188-0

Cheng, J., Chen, S., \& Chuang, Y. (2008). An application of Fuzzy Delphi and Fuzzy AHP for multi-criteria evaluation model of Fourth Party Logistics. WSEAS Transactions on Systems, 7(5), 466-478.

Cheng, J., Lee, C., \& Tang, C. (2009). An application of Fuzzy AHP on evaluating wafer supplier and semiconductor industry. WSEAS Transactions on Information Science and Applications, 6(5), 756-767.

Cheng, J., \& Tang, C. (2009). An application of Fuzzy Delphi and Fuzzy AHP for multi-criteria evaluation on bicycle industry supply chains. WSEAS Transactions on Systems \& Control, 4(1), 21-34.

Cho, J., \& Lee, J. (2013). Development of a new technology product evaluation model for assessing commercialization opportunities using Delphi method \& fuzzy AHP approach. Expert Systems with Applications, 40, 5314-5330. http://dx.doi.org/10.1016/j.eswa.2013.03.038

Chung, C. C., \& Her, M. T. (2013). Port State Control perception of the safe management of bulk carrier. Proceedings of the International Forum on Shipping, Ports \& Airports (IFSPA) 2013 (pp. 435-444). Hong Kong, Hong Kong Polytechnic University.

Da Cruz, M. R. P., Ferreira, J. J., \& Azevedo, S. G. (2013). Key factors of seaport competitiveness based on stakeholder perspective: An Analytic Hierarchy Process (AHP) model. Maritime Economics \& Logistics, 15(4), 416-443. http://dx.doi.org/10.1057/mel.2013.14

Dalkey, N., \& Helmer, O. (1963). An Experimental Application of the Delphi Method to the Use of Experts. Management Science, 9(3), 458-467. http://dx.doi.org/10.1287/mnsc.9.3.458

Delbecq, A. L., Van de Van, A. H., \& Gustafson, D. H. (1975). Group Technique for program planning. Glenview, IL: Scott, Foresman \& Co.

Forman, E. H., \& Selly, M. A. (2001). Decision by objectives (1st ed.). Petersburg USA: World Scientific Pub Co.

Gagatsi, E., Giannopoulos, G., \& Aifandopoulou, G. (2014). Supporting policy making in maritime transport by means of multi-actors multi-criteria analysis: A methodology developed for the Greek maritime transport system. Transport Research Arena 2014 (pp. 1-12). Paris: TRA.

Gerdsri, N., \& Kocaoglu, D. (2007). Applying the Analytic Hierarchy Process (AHP) to build a strategic framework for technology road mapping. Mathematical \& Computer Modelling, 46(7-8), 1071-1080. http://dx.doi.org/10.1016/j.mcm.2007.03.015

Gordon, T. J. (2009). The Delphi Method. In J. C. Glenn, \& T. J. Gordon (Eds.), Futures Research Methodology, Version 3.0. Rockefeller Foundation. 
Grisham, T. (2009). The Delphi technique: A method for testing complex and multifaceted topics. International Journal of Managing Projects in Business, 2(1), 112-130. http://dx.doi.org/10.1108/17538370910930545

Gupta, U. G., \& Clarke, R. E. (1996). Theory and Applications of the Delphi Technique: A Bibliography (1975-1994). Technological Forecasting and Social Change, 53, 185-211. http://dx.doi.org/10.1016/S00401625(96)00094-7

Hasson, F., \& Keeney, S. (2011). Enhancing rigour in the Delphi technique research. Technological \& Forecasting \& Social Change, 78, 1695-1704. http://dx.doi.org/10.1016/j.techfore.2011.04.005

Hsu, C. C., \& Sandford, B. A. (2007). The Delphi Technique: Making Sense of Consensus, Practical Assessment. Research \& Evaluation, 12(10). Retrieved from http://pareonline.net

Hsu, P. H., \& Chen, B. Y. (2007). Developing and implementing a selection model for bedding retail store franchisee using Delphi and Fuzzy AHP. Quality \& Quantity, 41, 275-290. http://dx.doi.org/10.1007/s 11135-006-9004-z

Jeong, W. L. (2014). A study on the activation strategy for female maritime officers using AHP. Journal of Navigation \& Port Research, 38(1), 1-9. http://dx.doi.org/10.5394/KINPR.2014.38.1.1

Khademi, N., \& Shekholeslami, A. (2010). Multicriteria group decision-making technique for a low class road maintenance program. Journal of Infrastructure Systems, September, 188-198. http://dx.doi.org/10.1061/ (ASCE)IS.1943-555X.0000023

Kuo, R. J., Chi, S. C., \& Kao, S. S. (2002). A decision support system for selecting convenience store location through integration of fuzzy AHP and artificial neural network. Computers in Industry, 47, 199-214. http://dx.doi.org/10.1016/S0166-3615(01)00147-6

Kwiesielewicz, M. (1998). A note on the fuzzy extension of Saaty's priority theory. Fuzzy Sets and Systems, 95, 161-172. http://dx.doi.org/10.1016/S0165-0114(96)00329-6

Kwong, C. K., \& Bai, H. (2002). A fuzzy AHP approach to the determination of importance weights of customer requirements in quality function deployment. Journal of Intelligent Manufacturing, 13, 367-377. Kluwer Academic Publisher. http://dx.doi.org/10.1023/A:1019984626631

Lee, C., Wan, J., Shi, W., \& Li, K. (2014). A cross-country study of competitiveness of the shipping industry. Transport Policy, 35, 366-376. http://dx.doi.org/10.1016/j.tranpol.2014.04.010

Lee, J. W., \& Kim, S. N. (2001). An integrated approach for interdependent information system project selection. International Journal of Project Management, 19, 111-118. http://dx.doi.org/10.1016/S0263-7863(99) 00053-8

Liao, C. N. (2010). Supplier selection project using an integrated Delphi, AHP \& Taguchi Loss Function. ProbStat Forum, 3, 118-134.

Linstone, H., \& Turoff, M. (Eds.) (1975). The Delphi Methods: Techniques and Applications. Reading, MA: Addison-Wesley.

Lirn, T. C., Thanopoulou, H., Benon, M., \& Beresford, A. (2004). An application of AHP on transhipment port selection: A global perspective. Maritime Economics and Logistics 6(1), 70-91. http://dx.doi.org/10.1057/ palgrave.mel.9100093

Ludwig, B. (1997). Predicting the future: Have you considered using the Delphi methodology? Journal of Extension, 35(5), 1-4.

Mishra, S., Desmukh, S., \& Vrat, P. (2002). Matching of technological forecasting technique to a technology. Technology Forecasting \& Social Change, 69(1), 1-27. http://dx.doi.org/10.1016/S0040-1625(01)00123-8

Moradi, A., Etebarian, A., Shirvani, A., \& Soltani, I. (2014). Development of a fuzzy model for Iranian marine casualties management. Journal of Fuzzy Set Valued Analysis, 1-17. http://dx.doi.org/10.5899/2014/jfsva00186

Oguztimur, S. (2011). Why Fuzzy Analytic Hierarchy Process Approach for Transport Problems? European Regional Science Association/IDEAS. Retrieved June 17, 2013, from http://www.screawu.ac

Powell, C. (2003). The Delphi technique: myths and realities. Journal of Advanced Nursing, 41(4), 376-382. http://dx.doi.org/10.1046/j.1365-2648.2003.02537.x

Rowe, G., \& Wright, G. (1999). The Delphi technique as a forecasting tool: Issues and analysis. International Journal of Forecasting, 15, 353-375. http://dx.doi.org/10.1016/S0169-2070(99)00018-7 
Rowe, G., \& Wright, G. (2011). The Delphi Technique: Past, Present and Future Prospects-Introduction to the Special Issue. Technological Forecasting \& Social Change, 78, 1487-1490. http://dx.doi.org/10.1016/j. techfore.2011.09.002

Saaty, T. L. (1986). Axiomatic Foundation of the Analytic Hierarchy Process. Management Science, 32(7), 74-87. http://dx.doi.org/10.1287/mnsc.32.7.841

Saaty, T. L. (1997). Discussion: That is Not the Analytic Hierarchy Process: What the AHP Is and What It are not. Journal of Multi-Criteria Decision Analysis Anal, 6, 324-335. http://dx.doi.org/10.1002/(SICI)1099-1360 (199711)6:6<324::AID-MCDA167>3.0.CO;2-Q

Saaty, T. L. (2002). How to make and justify a decision: The Analytic Hierarchy Process. System Research and Information Technologies, 1, 95-108.

Saaty, T. L., \& Tran, L. T. (2007). On the invalidity of fuzzifying numerical judgments in the Analytic Hierarchy Process. Mathematical and Computer Modelling, 46, 962-975. http://dx.doi.org/10.1016/j.mcm.2007. 03.022

Saaty, T. L. (2008). Decision making with analytic hierarchy process. International Journal of Services Sciences, 1(1), 83-98. http://dx.doi.org/10.1504/IJSSCI.2008.017590

Sayareh, J., \& Alimini, H. R. (2014). A hybrid decision-making model for selecting container seaport in the Persian Gulf. The Asian Journal of Shipping and Logistics, 30(1), 75-95. http://dx.doi.org/10.1016/j.ajsl. 2014.04.004

Sekaran, U., \& Bougie, R. (2010). Research Method for Business, a Skill Building Approach (5th ed.). Chichester UK: John Wiley \& Sons Ltd.

Skulmoski, G. J., Hartman, F. T., \& Krahn, J. (2007). The Delphi Method for Graduate Research. Journal of Information Technology Education, 6, 1-21.

Steward, J. (2001). Is the Delphi technique a qualitative method? Medical Education, 35, 922-923. http://dx.doi. org/10.1111/j.1365-2923.2001.01045.x

Tavana, M., Kennedy, D., \& Joglekar, P. (1996). A group decision support framework for decision ranking of technical manager candidates. Journal of Management Science, 24(5), 523-538.

UNCTAD Secretariat. (2014). Review of Maritime Transport 2014. Geneva. United Nations Conference on Trade and Development.

Van Laarhoven, P. J. M., \& Pedrycz, W. (1983). A Fuzzy Extension of Saaty's Priority Theory. Fuzzy Sets and systems, 11(1-3), 199-227. http://dx.doi.org/10.1016/S0165-0114(83)80082-7

Vidal, L., Marle, F., \& Bocquet J. (2011). Using a Delphi process and the Analytic Hierarchy Process (AHP) to evaluate complexity of project. Expert Systems with Applications, 38(5), 5388-5404. http://dx.doi. org/10.1016/j.eswa.2010.10.016

Wu, C. H., \& Fang, W. C. (2011). Combining the Fuzzy Analytic Hierarchy Process and the Fuzzy Delphi method for developing critical competencies of electronic commerce professional managers. Quality \& Quantity, 45, 751-768. http://dx.doi.org/10.1007/s11135-010-9425-6

Yang, C., Liu, T., Kao, C., \& Wang, H. (2010). Interpreting AHP \& Delphi methods to construct a green product assessment hierarchy for early stages of product design \& development. International Journal of Operations Research, 7(3), 35-43.

\section{Copyrights}

Copyright for this article is retained by the author(s), with first publication rights granted to the journal.

This is an open-access article distributed under the terms and conditions of the Creative Commons Attribution license (http://creativecommons.org/licenses/by/3.0/). 